\title{
Chapter 3 \\ Structures of German Emigration and Remigration: Historical Developments and Demographic Patterns
}

\author{
Andreas Ette and Marcel Erlinghagen
}

\subsection{Introduction}

Germany today is one of the world's most important countries of immigration. According to its official migration statistics, more than 37.6 million migrants have arrived in Germany over the past five decades. Whereas in its beginnings this migration was shaped by immigration from southern Europe, the countries of origin have become increasingly diverse. This heterogenisation of migration is also apparent in Germany's resident population. The German Microcensus, as the administrative national household survey, reports that 13.4 million migrants and over 7.3 million descendants of immigrants live in Germany today, demonstrating that international migration is a key factor for its population development as well as the social structure today. However, Germany is not only a country of immigration but also a major country of emigration. This includes the high migration dynamic of its immigrant population with the subsequent return of immigrants constituting a major share of today's migration experience. Germany is also a country of emigration with respect to the German-born population. Over the past three decades-between 1991 and 2018-more than 3.3 million German citizens have left the country whereas 2.5 million have returned (Destatis 2020). Today, 3.8 million Germans live outside Germany in another OECD country (OECD 2019). This chapter sets the scene for the following chapters in this volume. It describes the historical developments, the existing geographical patterns, and the demographic structures as well as individual motives of internationally mobile people.

\footnotetext{
A. Ette $(\bowtie)$

Federal Institute for Population Research, Wiesbaden, Germany

e-mail: andreas.ette@bib.bund.de

M. Erlinghagen

Institute of Sociology, University of Duisburg-Essen, Duisburg, Germany

e-mail: marcel.erlinghagen@uni-due.de
} 


\subsection{Historical Development of Emigration and Remigration from Germany}

Germany has a long tradition as a country of emigration. As early as the nineteenth century, Germany developed into a country of emigration. At that time, emigration from Germany, but also many other European countries, was primarily a transatlantic phenomenon. The agricultural crisis in Europe in the 1840s, the failed revolutions of 1848/49, and the discovery of gold in California and Australia in the 1850s caused emigration figures to rise, especially in North-western and Central Europe. In Germany, this transatlantic emigration gained importance from the 1830s onwards (Bade 1992). Accurate figures about the development of those historical migration flows hardly exist. Various countries existed at that time on today's territory of Germany and the whole concept of emigration and remigration is questionable in an era of nation-building and state formation when borders and ethno-national affiliations were in flux. Nevertheless, existing estimates assume that between 1816 and 1914 approximately 5.5 million Germans emigrated overseas. Particularly the years between 1846-57 and 1864-73 were major emigration phases with more than one million emigrants each. An additional 1.8 million emigrants followed in the final major emigration phase of 1880-93. The year 1893 is often referred to as the end of mass emigration before the First World War and from 1894 to 1918 the emigration figures registered in Germany were comparable to those of the early 1840s only.

The main destination of German emigrants at that time was the United States of America (USA), to which about $80-90 \%$ of emigrants relocated. The population born in Germany in the USA in 1820-60 was the second strongest immigrant group after the Irish (around 30\%), and in 1861-90 it was the strongest (Oltmer 2010, p. 10). Other important overseas emigration destinations were Canada, Brazil, Argentina, and Australia. Although overseas emigration dominated migration at the time, emigration to other European countries was also important. Around 1900, about 740,000 Germans were registered there. The largest group at that time, with almost 220,000 people, lived in Switzerland. Other important target countries with large German population groups were Russia, the Austrian countries, France, Belgium, and Great Britain. Compared to today, particularly overseas emigration was planned permanently but even then it is assumed that approximately $30 \%$ of German emigrants returned (for more details see also Ette and Sauer 2010).

The reasons for the sharp increase in emigration during the nineteenth century were low economic growth, and stagnation in the demand for labour coupled with a dynamically developing population size. This economic constellation varied greatly between the regions within Germany. Whereas emigration started first in the southwest of Germany, in the northeast and especially in Mecklenburg and Brandenburg it began in the late 1840s and early 1850s, while Pomerania, West Prussia and Poznan followed a decade later. The relocation of the main emigration area from the southwest to the northeast also shifted the professional and social structure of the emigrants: Until the 1860s, self-employed small farmers, small traders, and small 
artisans were the most important occupational groups of the emigrants. With the shift of the focus to the northeast, the group of emigrants increasingly consisted of day labourers and peasant sons. Since the 1890s, the share of secondary and tertiary employment in overseas emigration grew steadily, but lagged significantly behind the growth of the corresponding share of employees on the labour market of the emigration country (Marschalck 1973, 77f.).

The considerable expansion of economic opportunities offered by high industrialisation and agricultural modernisation in Germany became a major factor in the decline in overseas emigration at the end of the nineteenth century. Only after the First World War did emigration from Germany increase again, albeit to a lesser extent than in the period before. It is estimated that between 1919 and 1932 about 603,000 Germans emigrated overseas. Germany was at that time again one of the major European emigration countries alongside the British Isles, Italy, Portugal, and Spain. Following the stabilisation of the currency at the end of 1923 and US immigration restrictions in 1924 (Fischer 1987, p. 37), however, the number of German emigrants fell again and, during the global economic crisis of the early 1930s, amounted to only 10,000 to 15,000 persons per year. Furthermore, the importance of the countries of destination changed away from the USA to Brazil and Argentina.

Political emigration and Jewish refugee migration from National Socialist Germany was a fundamentally different development of emigration (Bade 2004, p. 314). This emigration took place in phases, reflecting the pressure from Hitler's takeovers and the early measures to combat domestic political opponents as well as the first anti-Semitic laws until the Nuremberg Laws of 1935. The last wave of emigration began with the open violence against Jews during the November Pogroms. It ended with the beginning of the Second World War, which drastically reduced the possibilities for emigration and, after the ban on emigration in 1941, led to the genocide of German and European Jews (Röder 1992, p. 347; Oltmer 2010, p. 42). The number of Jewish emigrants is estimated at between 450,000 and 600,000. In 1933, $75 \%$ of this emigration was still concentrated in European states, but from 1934 onwards the majority of Jewish emigrants sought refuge in non-European states, especially in the USA, Palestine, and Argentina. In addition, numerous individuals from the cultural and scientific fields as well as other ethnic and cultural groups left Germany, as well as people who were persecuted for their political work in Germany, Austria, and other occupied territories.

In the years immediately following the Second World War, migration in Germany was essentially characterised by the large number of displaced persons. Largely in line with the situation after the First World War, the emigration of Germans played only a subordinate role due to the restrictive immigration regulations of the Allied states towards German citizens. Immigration was only open to German spouses and children of foreign nationals, recognised persecutees of the Nazi regime and particularly sought-after German scholars and highly qualified persons. The founding of the Federal Republic and the acceptance of the entry of Germans by the then most important countries of destination-the USA, Canada, and Australia-created the basis for a sharp increase in overseas emigration from the beginning of the 1950s. In addition to marriage migration by Allied soldiers stationed in Germany, the 
targeted recruitment of German workers by Western European states, Australia, and Canada explain this high level of emigration during the 1950s (Steinert 1992, 389f.). During the early 1960s, the economic upswing in Germany led to a noticeable decline in the emigration of Germans.

Reliable statistical data about the international migration of German citizens are only available from the late 1960s onwards after a proper population register was implemented in Germany and several conceptual and spatial changes following the Second World War came into place. In the 1970s, an average of about 56,000 Germans emigrated per year. Since then, this figure has been slowly increasing with 62,000 in the 1980s and 92,000 in the 1990s. The first decade after the turn of the millennium saw an obvious increase to an average of 125,000 emigrants per year, stabilising since then at this level with 132,000 in the years 2010 to 2018 (see Fig. 3.1).

Considering the emigration rate, there has been a marked increase: While the emigration rate was below one per mill during the 1970s, it has almost doubled to

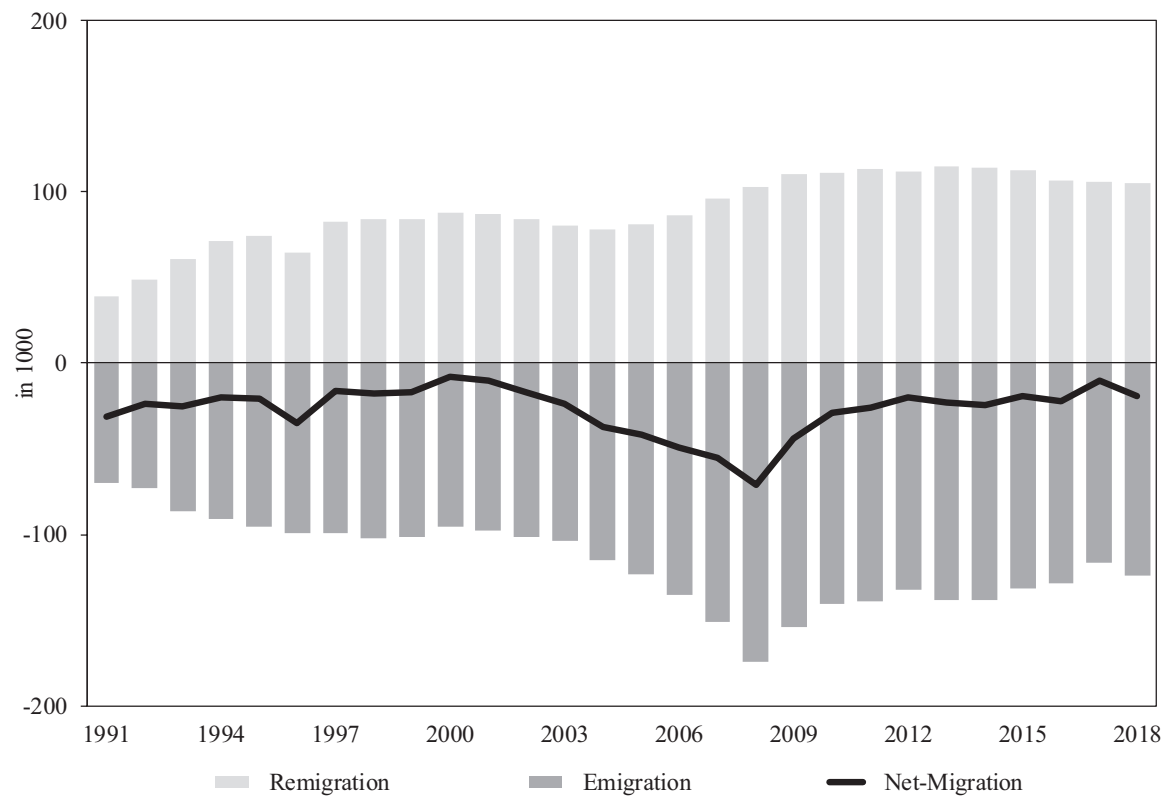

Fig. 3.1 Development of emigration, remigration and net migration of German citizens, 1991-2018, in 1000. (Sources: Federal Statistical Office 2019, Federal Office of Administration 2019, authors' calculations). Notes: The official migration statistic is derived from Germany's population registers. Due to their administrative background, there have been regular changes in the underlying procedure and necessary adjustments to the population registers in recent decades. In order to allow for temporal comparison, the figure is based on data about outflows and inflows of German citizens, whereby deregistrations "ex officio" as well as to unknown foreign countries are not taken into account. This procedure excludes in particular statistical artefacts resulting from register adjustments in the years 2004-2007 as well as a change in the registration procedure from 2016 onwards. Current figures on the international mobility of Germans have been significantly higher since 2016, but this is due to a change in procedure. Furthermore, the statistics exclude the inflows of ethnic Germans, as this is also a specific form of migration that should not be combined with the forms of international mobility that are the focus of this book 
1.8 per mill in the years since 2010 . Thus, in absolute numbers as well as in proportion to the population as a whole, the population is internationally significantly more mobile today than in previous decades. Focusing on the last three decades, the remigration of German citizens returning to Germany is laterally reversed to emigration. Figure 3.1 shows that the yearly average return migration rate in the 1990s was about 68,000 remigrants and increased afterwards to 89,000 in the first decade after the turn of the millennium to 111,000 for the years since 2010. The fact that the dynamic of return migration follows emigration on a slightly lower level results in a negative migration balance throughout the last three decades. For the whole period from 1991 to 2018, overall 758,000 more German citizens emigrated than returned afterwards, resulting in an average annual negative migration balance of approximately $-27,000$ Germans.

\subsection{Geography of Departure and Arrival}

In addition to potential historical path dependencies, the geographical pattern of departure and arrival also provides an important context to help understand the recent international mobility of German citizens. Existing studies on the demographic selectivity of migration in Germany focus in particular on interregional relocations documenting stark regional differences (e.g. Gatzweiler 1975; Schlömer 2009). In line with these findings, the geography of departure of international migrations also highlights obvious regional discrepancies. The most obvious result concerns differences between the old and the new federal states. On average, 101,000 people emigrated from former West Germany every year in 2017-18, while only 19,000 people from former East Germany (including Berlin) opted for international migration. In line with the procedure adopted in Fig. 3.1, all subsequent analyses based on Germany's official migration statistics rely on average results for the years 2017 and 2018 and always exclude registrations "ex officio" in order to increase comparability of these data. Considering the emigration rate, a significant difference remains: On average, 0.8 of every 1000 persons in the new federal states move abroad, while in the old federal states this rate is 1.7 of every 1000 (cf. Fig. 3.2). The highest emigration rates are found in Baden-Württemberg $(0.28 \%)$ followed by the city-states of Berlin $(0.28 \%)$, and Hamburg $(0.23 \%)$. Overall, the spatial pattern of remigration is the reverse of the geography of departure. The remigration rate, for example, is 1.5 of every 1000 people in the old federal states and 0.8 in the new federal states. The highest rates are again found in Baden-Württemberg, Berlin, and Hamburg. Because of this close relationship, all subsequent analyses focus on emigration only.

Significant regional differences also exist within the federal states. There is, firstly, a regional difference below the level of the federal states between urban and rural areas. Classifying the administrative districts along their settlement structure (BBSR 2019) shows that the emigration rate of major cities (0.22\%) is much higher than in urban districts $(0.17 \%)$, rural districts $(0.13 \%)$, and peripheral rural areas 


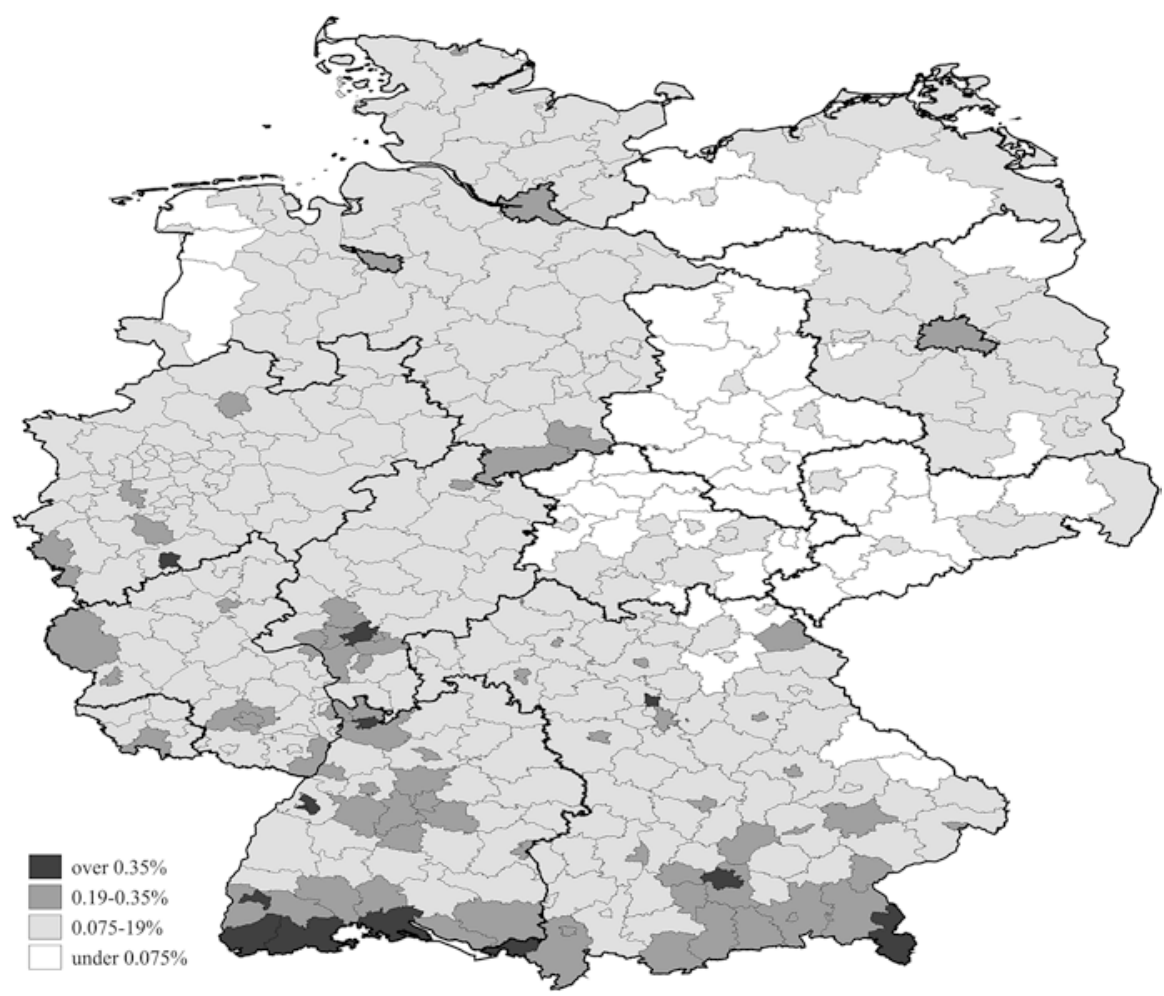

Fig. 3.2 Emigration rate of German citizens by administrative districts (average of the years 2017-18, in per cent). (Source: Federal Statistical Office 2019, authors' calculations and presentation)

$(0.11 \%)$. Figure 3.3 highlights the relationship between the population density of Germany's administrative districts and its emigration rate. The large cities and conurbations in particular exhibit a high migration volume with foreign countries. In addition to the aforementioned cities of Berlin and Hamburg, this includes in particular Munich, Cologne, and Frankfurt showing the highest numbers of emigrants.

Although three-quarters of all emigrants originate from major cities and urban districts, the population density hardly predicts the emigration rate $\left(r^{2}=0.10\right)$. Economic and geographic factors are of greater importance for explaining the heterogeneity of the geography of departure. Figure 3.3 highlights the relationship $\left(r^{2}=0.22\right)$ between the share of employees with academic degrees in Germany's 401 academic districts with the resulting emigration rate. This also puts much smaller cities like Heidelberg and Freiburg on the map, both having substantial numbers of international German migrants. Larger cities likely host transnational companies but also academic institutions, both contributing to increased emigration from these regions. Finally, proximity to the border also makes a difference. Taking into account that districts with an international border are regularly less urbanised, the direct proximity to a foreign country has a positive effect on the emigration rate 

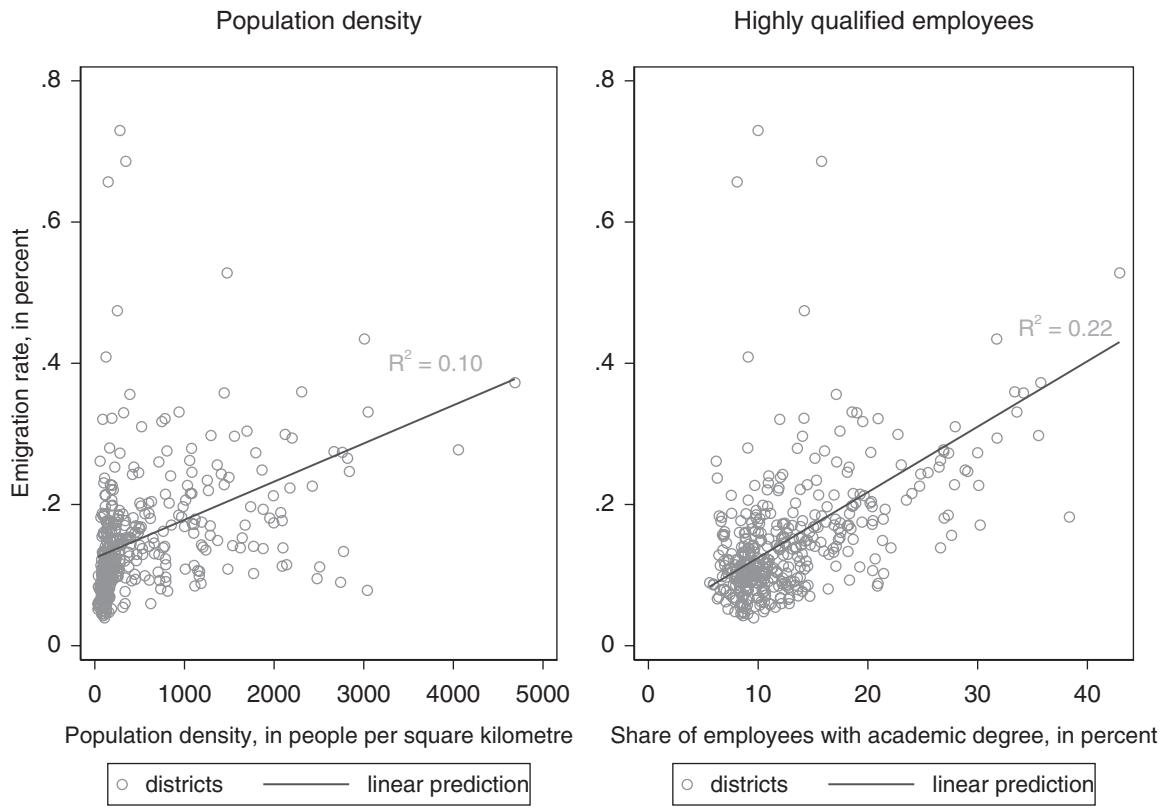

Fig. 3.3 Emigration rate of German citizens by administrative districts and their population density as well as share of highly qualified employees (average of the years 2017-18, in per cent). (Sources: Federal Statistical Office 2019, Federal Institute for Research on Building, Urban Affairs and Spatial Development 2019; authors' calculations and presentation)

of those districts. Examples include in particular Lörrach, Konstanz, and Waldshut sharing a border with Switzerland, Garmisch-Partenkirchen, and Berchtesgadener Land at the border to Austria, and Aachen at the Dutch, as well as Saarbrücken at the French border. The federal states in former East Germany bordering the new EU member states-Poland and the Czech Republic-show no statistically significant effect.

Emigration from Germany is a highly selective process in terms not only of regions of origin, but also in terms of destination countries and regions. Figure 3.4 provides an initial overview of the spatial pattern of emigration showing the average emigration of German citizens to the various destination countries for the years 2017 and 2018. Emigration from Germany is an overwhelmingly European phenomenon. Of an average of 121,000 emigrants per year during those last two years, $64.7 \%$ emigrated to other European states, with about 43,600 emigrating to the 14 member states of the European Union (EU) that joined the EU before the year 2004, and another 9900 to the new accession states from the enlargement rounds since 2004. A further 24,100 Germans emigrated to other European countries, with Switzerland being by far the most important destination, with an average of 16,100 emigrants in 2017-18.

Figure 3.5 shows the average number of emigrants during the year 2017-18 to all major destination countries. Although there is a negative relationship between the distance between Germany and the destination country and the number of emigrants 


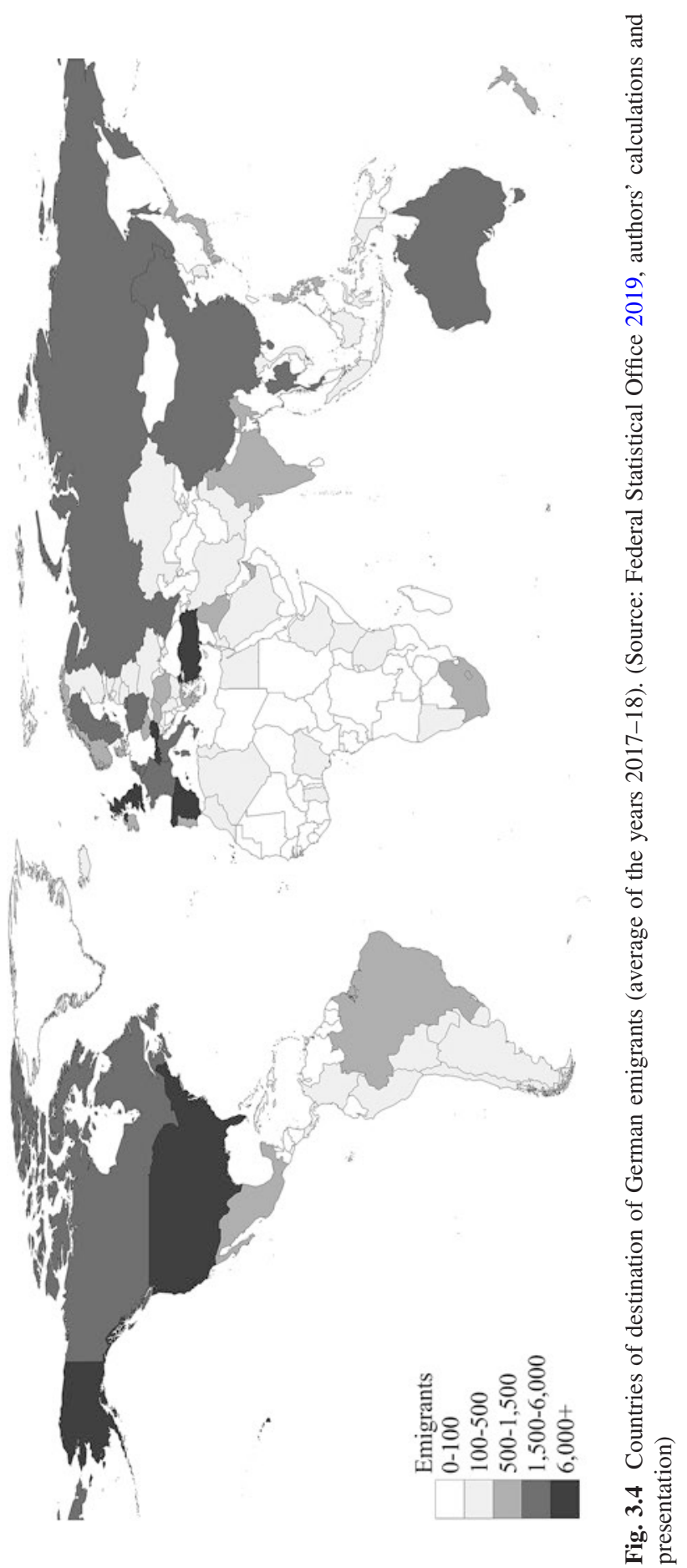



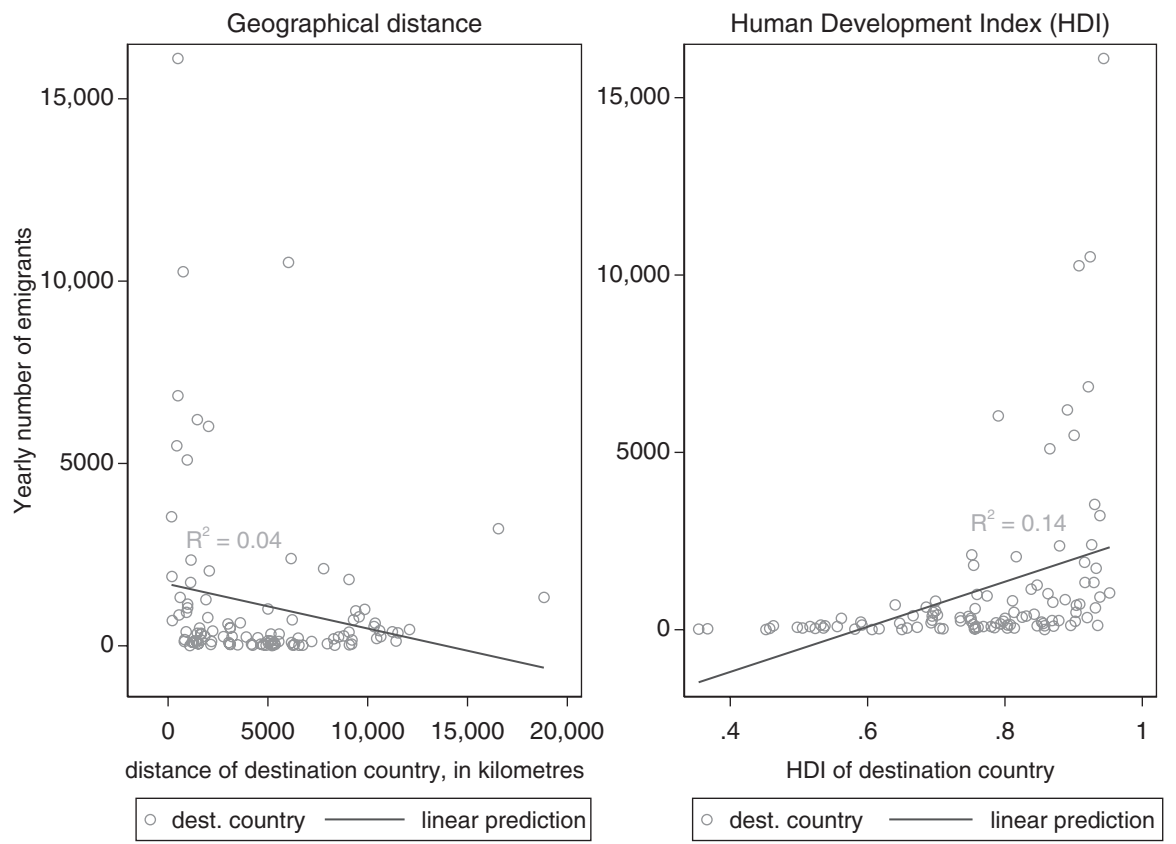

Fig. 3.5 German emigrants by country of destination and their geographical distance to Germany as well as their human development index (average of the years 2017-18). (Source: Federal Statistical Office 2019, authors' calculations and presentation)

those countries attract, the influence of geographical distance in shaping emigration patterns from Germany is of little relevance. In Asia, major destination countries are China (2100 emigrants), and Thailand (1800 emigrants), in South America and Africa they are Brazil (1000 emigrants), Mexico (1000 emigrants), and South Africa (800 emigrants). The living standard in potential countries of destination is of greater importance than spatial proximity. Measured by the Human Development Index (HDI) it is of greater relevance $\left(r^{2}=0.14\right)$ in shaping patterns of emigration. Consequently, classic immigration countries such as the USA $(10,500)$, Australia (3200), and Canada (2400) also attract substantial numbers of Germans who emigrate despite their distance to Germany (see Fig. 3.5).

Europe's position as the most important region of destination for German emigrants has only developed in recent decades. The emigration of Germans during the nineteenth century and up to the middle of the twentieth century had a strongly transatlantic character, while migration to other European states played only a subordinate role. The Europeanisation of emigration from Germany is thus still a relatively recent process that has only developed over the past few decades and is certainly influenced by the institutional changes within the EU during the last decade with the increasing free movement regime. Within Europe, however, certain shifts with respect to major countries of destination have emerged. 


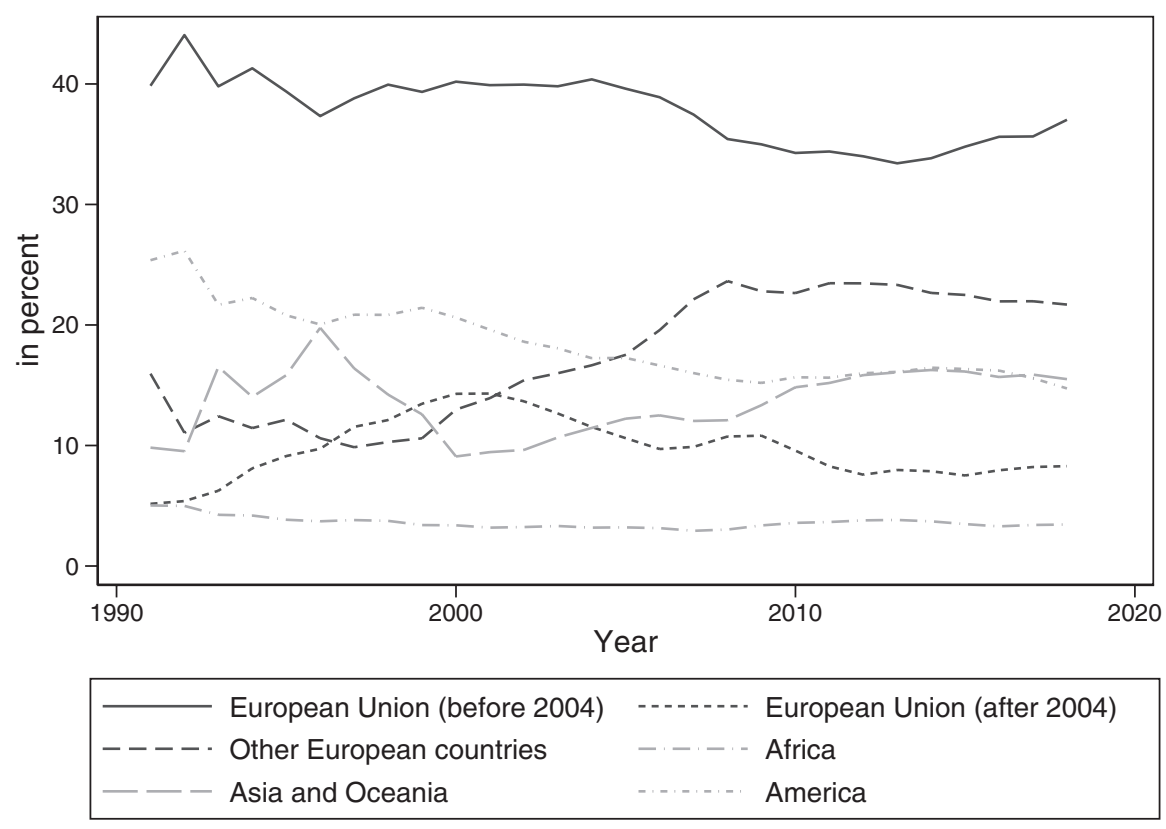

Fig. 3.6 Development of major regions of destination of German emigrants, 1991-2018, in per cent. (Source: Federal Statistical Office 2019, authors' calculations and presentation)

Figure 3.6 shows that the 14 EU member states have a relatively fixed yearly share of German emigrants ranging between $33.4 \%$ and $44.1 \%$ throughout the last three decades between 1991 and 2018. The share of the new member states joining the EU after 2004 as countries of destination for German emigrants fluctuated much more. Whereas their share increased in the long run from $5.2 \%$ in the early 1990 s to $8.3 \%$ in 2018 , it peaked at $14.3 \%$ in the year 2000. European countries outside of the European Union are of greatest importance for the more recent Europeanisation trend of German emigration, with Switzerland certainly being of greatest importance, but also Turkey now being one of the most important countries of destination. The Americas as a region of destination is continually losing its attractiveness for German emigrants: Its original share of $26.2 \%$ in the early 1990s decreased to $14.7 \%$ in 2018 . This is only partly explained, however, by the United States, which remains one of the two major countries of destination throughout the entire last three decades (see Table 3.1).

The classic immigration countries such as Canada and Australia, but also countries such as Brazil and South Africa, have consistently lost importance. South Africa has no longer been one of the 15 most important destination countries since the early 1990s. Countries with particularly high numbers of ethnic Germans had gained in importance during the 1990s but this trend has come to end as well. In the case of Kazakhstan and the Russian Federation, for example, it can be assumed that Germans who originally arrived in Germany as ethnic Germans under resettlement 
3 Structures of German Emigration and Remigration: Historical Developments...

Table 3.1 Development of major countries of destination of German emigrants, 1991-2018

\begin{tabular}{l|l|l|l|l}
\hline Rank & 1991-1997 & 1998-2004 & 2005-2011 & 2012-2018 \\
\hline 1 & USA & USA & Switzerland & Switzerland \\
\hline 2 & France & Poland & USA & USA \\
\hline 3 & Netherlands & Switzerland & Austria & Austria \\
\hline 4 & Switzerland & Spain & Poland & United Kingdom \\
\hline 5 & Poland & France & United Kingdom & Turkey \\
\hline 6 & Spain & United Kingdom & Spain & Spain \\
\hline 7 & Kazakhstan & Austria & France & France \\
\hline 8 & Austria & Netherlands & Turkey & Poland \\
\hline 9 & United Kingdom & Italy & Canada & Netherlands \\
\hline 10 & Italy & Belgium & Netherlands & Australia \\
\hline 11 & Belgium & Canada & Australia & China \\
\hline 12 & Russian Federation & Australia & Italy & Canada \\
\hline 13 & Canada & Kazakhstan & Russian Federation & Italy \\
\hline 14 & Australia & Russian Federation & Belgium & Russian Federation \\
\hline 15 & Brazil & Turkey & China & Belgium
\end{tabular}

Source: Federal Statistical Office 2019, authors' calculations and presentation

law regulations are now returning to their former home countries (Schönhuth 2008). The most recent developments of German emigration include the increasing flows towards Turkey and China, which can be attributed in particular to the economic development in both countries, but also to the increasing number of naturalised Turkish returnees. Furthermore, the German speaking countries of Switzerland and Austria have gained importance as countries of destination in recent years.

\subsection{Demographic Structures of the Internationally Mobile Population}

In addition to the specific geography of departure and arrival, the demography of emigration and remigration shows distinctive structures that are linked to the individual life course. Whereas all previous analyses in this chapter referred to administrative data from Germany's population statistics, all subsequent analyses refer to survey data. The German Emigration and Remigration Panel Study (GERPS) collected this data for the internationally mobile population, whereas data from the Socio-economic Panel (SOEP) is used for the internationally non-mobile population in Germany (for more information see Ette et al. 2021).

International migration is, in the first place, a domain of younger individuals (Rogers and Castro 1981; Plane 1993). This is the case because the process of family formation and educational and career-related events coincide between the age of 20 and 40 and often go hand in hand with a greater need or demand for spatial mobility (Mulder and Wagner 1993; Kulu and Billari 2004; Venhorst et al. 2011; 
Bernard et al. 2014). In addition, younger individuals have less residence-related investments such as home ownership or strong social relationships with colleagues and neighbours, which increase the social costs of mobility for older individuals (DiPasquale and Glaeser 1999; Fischer and Malmberg 2001; David et al. 2010).

Compared to the non-mobile population in Germany, German emigrants and remigrants are significantly younger. Among older individuals, emigration becomes less prevalent as can be seen in the lower numbers compared to the non-mobile population (see Table 3.2). We see a comparable development with regards to remigration with slightly older remigrants on average (emigrants: 36.5 years, remigrants: 36.8 years). Furthermore, there are no substantial gender differences in emigration or remigration prevalence. However, female German emigrants as well as remigrants are on average about 2.5 years younger than internationally mobile males. This is in line with age-related gender differences regarding moves within Germany due to differences in career decisions and family formation processes, but also with regard to differences in preferences and attitudes between men and women (Kröhnert and Vollmer 2012; Bernard et al. 2014).

Marital status is another demographic aspect. Again, obvious differences between the internationally mobile and non-mobile population exist (see Table 3.2). Whereas about $55 \%$ of the German non-mobile population is married, only about $40 \%$ of emigrants and remigrants are married. Also, emigrants and remigrants show much higher numbers of unmarried individuals $(53.1 \%$ and $51.9 \%$ vs. $31.6 \%)$. This largely reflects the age structures of migrants and the non-mobile population. Since the propensity of marriage increases with age but younger people are highly overrepresented among international German migrants this finding is not surprising. This also explains the higher share of divorced and widowed individuals among the non-mobile population. Finally, we find a higher share of registered same-sex partnerships among the internationally mobile population.

Among emigrants and remigrants, we also find a comparable high share of Germans with migration background, which means that their parents or they themselves were born outside Germany (first or second-generation migrant). Table 3.2 shows that among non-mobile German citizens about $8 \%$ are first-generation migrants and about 5\% are second-generation migrants. Among German emigrants the share of individuals with migration background is about $27 \%$ and among the remigrants it is even higher with $32 \%$. In particular, the share of internationally mobile second-generation migrants is much higher compared to the non-mobile population. It can be assumed that these individuals can benefit from migrationspecific human capital provided within their migration-experienced families. Furthermore, one could expect that first and second-generation migrants prefer to migrate to their own or to their parents' country of origin. This seems to be quite likely because we can assume that there is some origin-related transnational human capital (e.g. language skills) or transnational social capital (e.g. relatives) that can be utilised by emigrants. However, about three-quarters of German emigrants with a migration background move to other places than the country of their parents' origin $(66.2 \%$ of the first-generation emigrants and $80.7 \%$ of the second-generation migrants). There are differences if we compare recent emigrants with recent 
3 Structures of German Emigration and Remigration: Historical Developments...

Table 3.2 Socio-demographic structure of German emigrants and remigrants compared to the non-mobile population (aged 20-70 years), in per cent

\begin{tabular}{l|l|l|l}
\hline & Emigrants & Remigrants & Non-mobile \\
\hline Gender & & & \\
\hline Male & 52.6 & 51.4 & 50.1 \\
\hline Female & 47.4 & 48.6 & 49.9 \\
\hline Age & & & \\
\hline $20-29$ & 32.8 & 33.5 & 15.1 \\
\hline $30-39$ & 35.4 & 31.0 & 17.0 \\
\hline $40-49$ & 14.7 & 16.4 & 19.2 \\
\hline $50-59$ & 11.6 & 12.6 & 26.3 \\
\hline $60-70$ & 5.5 & 6.5 & 22.3 \\
\hline Marital Status & & & \\
\hline Married & 39.7 & 40.7 & 54.1 \\
\hline Unmarried & 53.1 & 51.9 & 31.6 \\
\hline Divorced & 3.8 & 5.0 & 11.0 \\
\hline Widowed & 0.3 & 0.4 & 2.9 \\
\hline Registered same-sex partnership & 3.1 & 2.0 & 0.4 \\
\hline Migration background & & & \\
\hline No migration background & 73.4 & 67.6 & 85.9 \\
\hline First-generation migrant & 11.6 & 15.3 & 8.4 \\
\hline Second-generation migrant & 13.1 & 15.4 & 5.7 \\
\hline Unspecified migration background & 1.9 & 1.7 & 0.0 \\
\hline Source: GERPSw1 & & & \\
\hline
\end{tabular}

Source: GERPSw1 for emigrants and remigrants, SOEP2017 for the non-mobile population

remigrants but even among the latter, we see high shares of first-generation (50.7\%) and second-generation migrants $(75.4 \%)$ who have lived in other places than their parents' country of origin (Table 3.3).

In addition to these demographic structures, emigration and remigration are also linked to other transitions within the life course. One aspect concerns changes in the household composition. Frequently, long distance moves and particularly international migration of couples and families are not synchronised but follow a pattern of sequential moves with one partner leading and the other following or, alternatively, the development of transnational family constellations because of longer-term spatial separation. Indeed, emigration from and remigration to Germany is accompanied by at least short-time changes in household composition (see Table 3.4). Comparing the household situation three months before emigration (wave 0 ) to the situation shortly after arrival (wave 1), the results show that particularly couples with no children and couples with dependent children (younger than 16 years old) report quite stable household compositions. Nevertheless, even in those households, we observe dynamic changes in the composition affecting 10-25\%. By contrast, a high number of adults living with no adult partner in the household three months before emigration report that they live together with an adult partner (again) in wave 1 , indicating a sequential timing of migration of those couples in most of these cases. With regard to remigration we see quite similar patterns, although there are 
Table 3.3 Destination of German emigrants with migration backgrounds concerning their parent's origin, in per cent

\begin{tabular}{l|l|l|l|l|l|l|l}
\hline & \multicolumn{4}{l}{$\begin{array}{l}\text { German emigrants with } \\
\text { migration background }\end{array}$} & \multicolumn{4}{l}{$\begin{array}{l}\text { German remigrants with } \\
\text { migration background }\end{array}$} \\
& First gen. & $\begin{array}{l}\text { Second } \\
\text { gen. }\end{array}$ & Total & First gen. & $\begin{array}{l}\text { Second } \\
\text { gen. }\end{array}$ & Total \\
\hline $\begin{array}{l}\text { Lives/has lived in country } \\
\text { of parent's origin }\end{array}$ & 33.8 & 19.3 & 25.9 & 49.3 & 24.6 & 36.4 \\
\hline $\begin{array}{l}\text { Lives/has lived in another } \\
\text { country }\end{array}$ & 66.2 & 80.7 & 74.1 & 50.7 & 75.4 & 63.6 \\
\hline Total & 100 & 100 & 100 & 100 & 100 & 100 \\
\hline
\end{tabular}

Source: GERPSw1

Table 3.4 Changes in household composition of emigrants comparing three months before emigration (wave 0 ) and wave 1 , in per cent

\begin{tabular}{l|l|l|l|l|l|l|l}
\hline & \multicolumn{5}{|l|}{ After migration (wave 1) } \\
\hline & $\begin{array}{l}\text { Single-person } \\
\text { household }\end{array}$ & $\begin{array}{l}\text { Couple, } \\
\text { no child }\end{array}$ & $\begin{array}{l}\text { Single } \\
\text { parent }\end{array}$ & $\begin{array}{l}\text { Couple, } \\
\text { child <16 }\end{array}$ & Other & $N$ \\
\hline $\begin{array}{l}\text { Before } \\
\text { migration } \\
\text { (wave 0) }\end{array}$ & $\begin{array}{l}\text { Single-person } \\
\text { household }\end{array}$ & $\mathbf{5 2 . 0}$ & 34.9 & 0.3 & 3.6 & 9.3 & 1617 \\
\cline { 2 - 9 } & $\begin{array}{l}\text { Couple, no } \\
\text { children }\end{array}$ & 15.9 & $\mathbf{7 3 . 5}$ & 0.1 & 5.3 & 5.2 & 845 \\
\cline { 2 - 9 } & Single parent & 3.3 & 4.9 & $\mathbf{3 2 . 8}$ & 57.4 & 1.6 & 61 \\
\cline { 2 - 10 } & $\begin{array}{l}\text { Couple, child } \\
\text { <16 }\end{array}$ & 5.2 & 0.2 & 1.3 & $\mathbf{9 1 . 8}$ & 1.5 & 478 \\
\cline { 2 - 9 } & Other & 33.3 & 32.3 & 0.4 & 5.8 & $\mathbf{2 8 . 2}$ & 694 \\
\hline & $N$ & 1232 & 1413 & 34 & 617 & 399 & \\
\hline
\end{tabular}

Source: GERPSw1

Bold data indicate the percentage of a particular household composition not changing between the situation before and after migration, e.g. $52.0 \%$ of all interviewed persons who lived in a singleperson household before migration still live in a single-person household also after migration

some indications of an overall lower dynamic of changes in the household composition (see Table 3.5).

Finally, we are interested in the links between migration and changes in relationship status. Overall, $15 \%$ of all emigrants and about $20 \%$ of all remigrants report a change in relationship status between three months before migration (wave 0) and the time of the interview after migration (wave 1) (see Table 3.6). Table 3.6 also shows the different timing patterns of migration for those emigrants and remigrants who report a stable relationship between wave 0 and wave 1 . Only a minority of the migrating couples moved simultaneously (emigrants: $35.8 \%$; remigrants: $45.7 \%$ ). In almost $24 \%$ of emigrant couples and about $20 \%$ of remigrant couples the partner already lived abroad (emigrants) or in Germany (remigrants) when they met for the 
3 Structures of German Emigration and Remigration: Historical Developments...

Table 3.5 Changes in household composition of remigrants comparing 3 months before emigration (wave 0 ) and wave 1 , in per cent

\begin{tabular}{|c|c|c|c|c|c|c|c|}
\hline & & \multicolumn{5}{|c|}{ After migration (wave 1) } & \multirow[b]{2}{*}{$N$} \\
\hline & & $\begin{array}{l}\text { Single- } \\
\text { person } \\
\text { household }\end{array}$ & $\begin{array}{l}\text { Couple, no } \\
\text { children }\end{array}$ & $\begin{array}{l}\text { Single } \\
\text { parent }\end{array}$ & $\begin{array}{l}\text { Couple, } \\
\text { child }<16\end{array}$ & Other & \\
\hline \multirow{6}{*}{$\begin{array}{l}\text { Before } \\
\text { migration } \\
\text { (wave 0) }\end{array}$} & $\begin{array}{l}\text { Single-person } \\
\text { household }\end{array}$ & 64.6 & 21.5 & 0.4 & 3.6 & 10.1 & 2059 \\
\hline & $\begin{array}{l}\text { Couple, no } \\
\text { children }\end{array}$ & 21.0 & 64.4 & 0.7 & 6.4 & 7.6 & 1203 \\
\hline & Single parent & 6.8 & 4.1 & 55.4 & 25.7 & 8.1 & 74 \\
\hline & $\begin{array}{l}\text { Couple, child } \\
<16\end{array}$ & 3.6 & 0.7 & 6.7 & 85.4 & 3.7 & 1083 \\
\hline & Other & 44.9 & 16.6 & 0.5 & 4.1 & 33.9 & 1364 \\
\hline & $N$ & 2237 & 1454 & 136 & 1150 & 806 & \\
\hline
\end{tabular}

Source: GERPSw1

Bold data indicate the percentage of a particular household composition not changing between the situation before and after migration, e.g. $64.6 \%$ of all interviewed persons who lived in a singleperson household before migration still live in a single-person household also after migration

Table 3.6 Relationship changes and timing of couples' migration for German emigrants and remigrants, in per cent

\begin{tabular}{l|l|l}
\hline & Emigrants & Remigrants \\
\hline Change in relationship & 15.0 & 19.6 \\
\hline Permanent single & 20.7 & 26.7 \\
\hline Permanent relationship & 64.3 & 53.7 \\
\hline $\begin{array}{l}\text { Among those with permanent relationship } \\
\text { partner already lived abroad/in Germany when we } \\
\text { met }\end{array}$ & 23.9 & \\
\hline partner moved abroad/to Germany in advance & 15.7 & 19.5 \\
\hline partner moved abroad/to Germany later & 10.5 & 9.8 \\
\hline simultaneous move & 35.8 & 12.8 \\
\hline partner still lives in Germany/abroad & 11.5 & 45.7 \\
\hline partner lives in another country & 2.6 & 9.2 \\
\hline
\end{tabular}

Source: GERPSw1

first time. Thus, in such cases migration is very likely to be a consequence of an initially bi-national or transnational relationship where the two partners now have decided to move in together at one place. Moreover, about $26 \%$ of emigrant and $21 \%$ of remigrant couples have obviously moved separately with one partner migrating in advance of their spouse. Finally about $14 \%$ of emigrants in a stable relationship have some kind of transnational relationship with the partner still living in Germany or in another country. The same holds true for about $12 \%$ of remigrants whose spouses are presently not living in Germany. 


\subsection{Individual Motives of International Mobility}

Heterogeneity with respect to the geography of departure and arrival as well as the specific demographic structure of internationally mobile Germans are also reflected by the individual motives of migration. There is a growing body of qualitative research that points to the heterogeneity of migration motives regarding mobility within the European Union (e.g. Bruquetas-Callejo 2019; Bygnes 2017; Cook et al. 2011). However, these studies often concentrate on migration from East to West Europe and/or on particular migrant groups. Therefore, it is questionable whether these results can be generalised with regard to other destination contexts and to other migrant groups. Existing quantitative studies about reasons of migration are rare. They either concentrate on migration intentions (see Dommermuth and Klüsener 2019 for a comprehensive literature review) or on retrospectively reported motives of actual migration (e.g. Luthra et al. 2018; Zwysen 2019). Whereas GERPS principally adopts both approaches, the following analyses are based on the latter approach. All GERPS respondents were asked to rate the importance of eight possible migration motives for their own migration decision retrospectively including, for example, their own professional reasons, professional reasons of their partner or financial reasons (see Table 3.7 for a full list of motives). The six-point rating scale ranges from, '1' ("not at all important") to '6' ("very important"). The GERPS participants not only could rate the importance of the different migration motives for their own decisions but can also indicate if any of the presented motives was not

Table 3.7 Share of emigrants and remigrants indicating certain migration reasons as (very) important $^{\mathrm{a}}$ in per cent

\begin{tabular}{l|l|l}
\hline & Emigrants & Remigrants \\
\hline Own professional reasons & 57.5 & 40.1 \\
\hline Professional reasons of my partner & 29.1 & 19.3 \\
\hline Other reasons regarding the partnership & 25.6 & 18.0 \\
\hline Family reasons & 20.8 & 39.7 \\
\hline Financial reasons & 26.4 & 19.9 \\
\hline $\begin{array}{l}\text { Dissatisfied with life in Germany / the country in } \\
\text { which I lived }\end{array}$ & 17.4 & 15.4 \\
\hline $\begin{array}{l}\text { Educational or training-related reasons / academic } \\
\text { studies }\end{array}$ & 19.8 & 24.4 \\
\hline $\begin{array}{l}\text { Reasons of personal lifestyle (e.g. better climate, } \\
\text { new exper.) }\end{array}$ & 45.1 & 21.5 \\
\hline $\begin{array}{l}\text { Recent political developments in the country where } \\
\text { I lived }\end{array}$ & - & 13.5 \\
\hline $\begin{array}{l}\text { Social security / support (e.g. healthcare, welfare, } \\
\text { childcare) }\end{array}$ & - & 25.4 \\
\hline $\begin{array}{l}\text { The UK's exit from the EU (Brexit) } \\
\text { b }\end{array}$ & - & 49.6 \\
\hline
\end{tabular}

Source: GERPSw1

${ }^{a}$ Rating importance with 5 or 6 on a six-point scale

${ }^{\mathrm{b}}$ Option only available for remigrants from the UK 
applicable. In this case, we interpret non-applicability as an indication of nonimportance of a certain motive.

Table 3.7 reports the share of all emigrants and remigrants who indicated that a certain motive was very important for their migration decision (ticking ' 5 ' or ' 6 ' on the six-point scale). For $57.5 \%$ of all emigrants, their own professional reasons were very important for their migration decision. Another important motive for emigration is a change in the personal lifestyle $(45.1 \%)$. The other reasons are of minor importance with shares of 20-30\%. Moreover, we can see that dissatisfaction with their life in Germany is of minor importance. Only $17.4 \%$ report that this reason was important for their emigration decision, whereas more than four-fifths of all German emigrants do not rate this as a crucial emigration reason. As for emigrants, their own professional reasons were also an important remigration motive with about $40 \%$ of all German remigrants reporting them as important. In contrast to emigration, a similar share of respondents indicates family reasons as crucial for their remigration decision. All other motives seem to be of minor importance with shares of about $20 \%$. In addition, only a small minority of remigrants report dissatisfaction with life abroad $(15.4 \%)$ or recent political developments in the host countries (13.5\%) as decisive remigration motives. Remigrants from the UK are one exception as $46 \%$ of them stated that the UK's exit from the European Union ("Brexit") was an important reason for them to return to Germany.

Another finding is that for most of the internationally mobile individuals not one single reason but some bundle of motives was relevant with regard to their migration decision. Figure 3.7 shows the share of emigrants and remigrants who report none

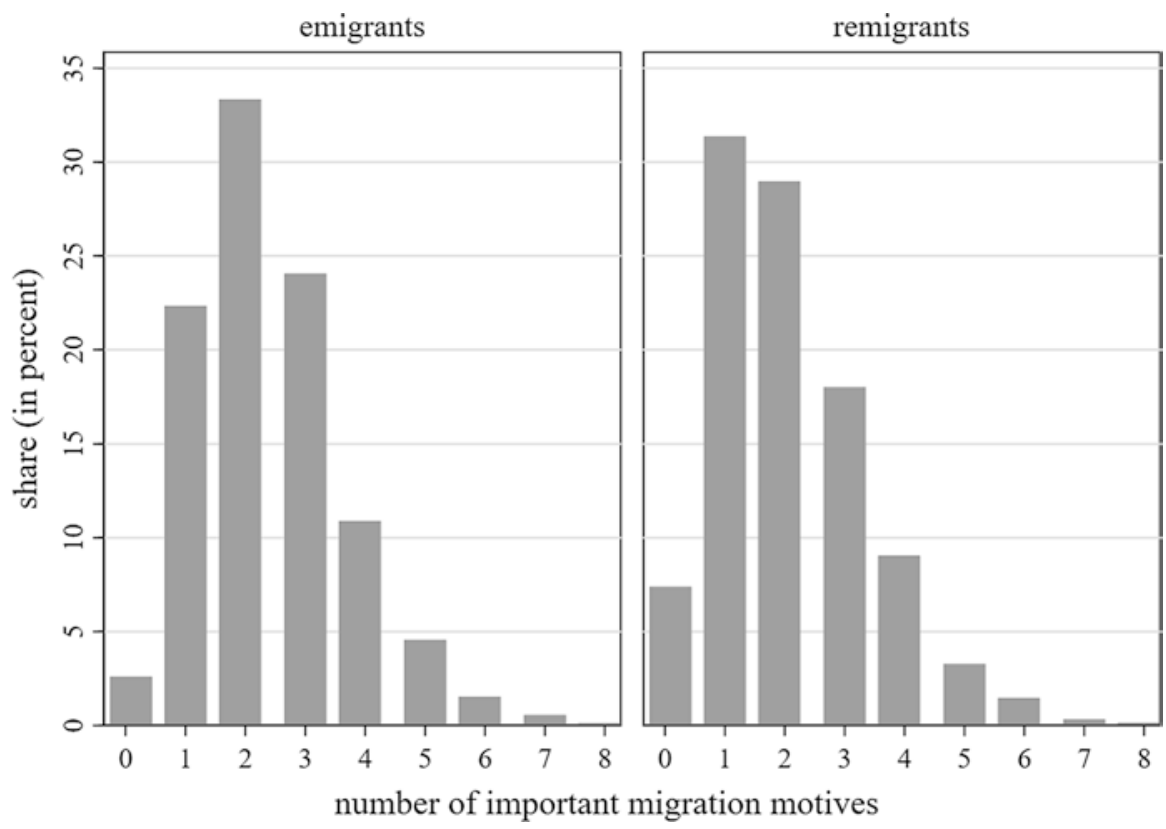

Fig. 3.7 Distribution of the number of important migration motives of German emigrants and remigrants, in per cent. (Source: GERPSw1) 
to eight important motives for their migration decision. For remigrants, the calculations are restricted to the eight motive categories that are also presented to emigrants. The majority of all emigrants and remigrants report about two or more important migration motives. Only a minority of about $22 \%$ (emigrants) or $31 \%$ (remigrants) said that their decision relied on only one important migration motive. Interestingly, some of the internationally mobile population fail to indicate any of the presented categories to be an important migration motive for them (about $3 \%$ of emigrants and $7 \%$ of remigrants).

\subsection{Conclusion}

The aim of this chapter was to set the scene for the following chapters in this volume and to describe basic structures of emigration and remigration from Germany. While Germany has developed over recent decades into one of the world's most important countries of immigration, it also continues its tradition as an emigration country. The last three decades showed a slowly increasing level of international mobility among the German population. Compared to previous periods of emigration, Europe has stabilised as the major region of destination while emigration to the Americas and other traditional countries of immigration has continuously decreased.

The place of residence in Germany makes a clear difference with respect to the probability of becoming internationally mobile. The resulting geography of departure shows that residents of the old federal states are more likely to migrate abroad than people from the new federal states. Furthermore, residents from urban areasand particularly those with larger well-qualified populations-are more likely to emigrate than people from rural districts. Additionally, residents from districts bordering the neighbouring countries in the south and the west have a higher probability of moving abroad.

Demographically, no substantial gender differences exist between emigrants and remigrants but in comparison to the non-mobile population in Germany, emigrants and remigrants are on average much younger. Additionally, internationally mobile females are even younger than their male counterparts. Former immigrants to Germany and their children (first or second-generation immigrant)-so-called German citizens with a migration background-have a higher prevalence of emigration and remigration compared to the population without a migration background. For those former immigrants to Germany and their children, the country of origin only plays a subordinate role. Particularly in the case of second-generation immigrants, more than three-quarters of them emigrated to or remigrated from another country than that of their parents' origins. Moreover, international mobility is accompanied by dynamics in household composition. Frequently, these changes in the household composition result from the non-synchronised timing of migrating couples and families. About 60-70\% of emigrating and remigrating couples report 
that one of both partners moved in advance or that the spouse is still living in Germany (emigrants) or the former destination country (remigrants).

The historical developments, geographical patterns, and demographic structures provide a highly heterogeneous picture of Germany's emigration and remigration experience. This impression is supported by a highly heterogeneous set of migration motives. Career-related motives are significant for emigrants as well as remigrants, but family-related motives are also of importance, particularly for remigrants. All in all, for most emigrants and remigrants international mobility is driven not by a single cause but is motivated by a bundle of heterogeneous reasons.

\section{References}

Bade, K. J. (Ed.). (1992). Deutsche im Ausland_Fremde in Deutschland. Migration in Geschichte und Gegenwart. München: C.H. Beck.

Bade, K. J. (2004). Sozialhistorische Migrationsforschung. Göttingen: V\&R unipress.

BBSR. (2019). Indikatoren und Karten zur Raum- und Stadtentwicklung-INKAR. Bonn: Bundesinstitut für Bau-, Stadt- und Raumforschung (BBSR) im Bundesamt für Bauwesen und Raumordnung (BBR).

Bernard, A., Bell, M., \& Charles-Edwards, E. (2014). Life-course transitions and the age profile of internal migration. Population and Development Review, 40(2), 213-239.

Bruquetas-Callejo, M. (2019). Long-term care crisis in the Netherlands and migration of live-in care workers: Transnational trajectories, coping strategies and motivation mixes. International Migration, 58(1), 105-118.

Bygnes, S. (2017). Are they leaving because of the crisis? The sociological significance of Anomie as a motivation for migration. Sociology, 51(2), 258-273.

Cook, J., Dwyer, P., \& Waite, L. (2011). The experiences of accession 8 migrants in England: Motivations, work and agency. International Migration, 49(2), 54-79.

David, Q., Janiak, A., \& Wasmer, E. (2010). Social capital, mobility and unemployment in Europe. Journal of Urban Economics, 68(2), 191-204.

Destatis. (2020). Wanderungen zwischen Deutschland und dem Ausland: Deutschland, Jahre, Staatsangehörigkeit. Wiesbaden: Statistisches Bundesamt.

DiPasquale, D., \& Glaeser, E. L. (1999). Incentives and social capital: Are homeowners better citizens? Journal of Urban Economics, 45, 354-384.

Ette, A., Décieux, J. P., Erlinghagen, M., Guedes Auditor, J., Sander, N., Schneider, N. F., \& Witte, N. (2021). Surveying across borders: The experiences of the german emigration and remigration panel study. In M. Erlinghagen, A. Ette, N. F. Schneider, \& N. Witte (Eds.), The global lives of German migrants. Consequences of international migration across the life course. Cham: Springer.

Ette, A., \& Sauer, L. (2010). Auswanderung aus Deutschland. Daten und Analysen zur internationalen Migration deutscher Staatsbürger. Wiesbaden: VS Verlag.

Federal Institute for Research on Building, Urban Affairs and Spatial Development. (2019). Indikatoren und Karten zur Raum- und Stadtentwicklung: INKAR 2019. Bonn: Federal Institute for Research on Building, Urban Affairs and Spatial Development.

Federal Office of Administration. (2019). Spätaussiedler und ihre Angehörigen. Jahresstatistik (several volumes). Cologne: Federal Office of Administration. 
Federal Statistical Office. (2019). Genesis-Online: Wanderungen zwischen Deutschland und dem Ausland. Wiesbaden: Federal Statistical Office.

Fischer, P. A., \& Malmberg, G. (2001). Settled people don't move: on life course and (im-)mobility in Sweden. International Journal of Population Geography, 7, 357-371.

Fischer, W. (Ed.). (1987). Europäische Wirtschafts- und Sozialgeschichte vom Ersten Weltkrieg bis zur Gegenwart. Handbuch der Europäischen Wirtschafts- und Sozialgeschichte, Bd. 6. Stuttgart: Klett-Cotta.

Gatzweiler, H. P. (1975). Zur Selektivität interregionaler Wanderungen. Ein theoretisch-empirischer Beitrag zur Analyse und Prognose altersspezifischer interregionaler Wanderungen. Bonn: Bundesforschungsanstalt für Landeskunde und Raumordnung.

Dommermuth, L., \& Klüsener, S. (2019). Formation and realisation of moving intentions across the adult life course. Population, Space and Place, 25(5), e2212.

Kröhnert, S., \& Vollmer, S. (2012). Gender-specific migration from Eastern to Western Germany: Where have all the young women gone? International Migration, 50(5), 95-112.

Kulu, H., \& Billari, F. (2004). Multilevel analysis of internal migration in a transitional country: The case of Estonia. Regional Studies, 38(6), 679-696.

Luthra, R., Platt, L., \& Salamonska, J. (2018). Types of migration: the motivations, composition, and early integration patterns of 'new migrants' in Europe. International Migration Review, 52(2), 368-403.

Marschalck, P. (1973). Deutsche Überseewanderung im 19. Jahrhundert. Ein Beitrag zur soziologischen Theorie der Bevölkerung. Stuttgart: Klett.

Mulder, C. H., \& Wagner, M. (1993). Migration and marriage in the life course: A method for studying synchronized events. European Journal of Population, 9(1), 55-76.

OECD. (2019). The new immigrants: Global trends in migration towards OECD countries between 2000/01 and 2015/16. Paris: Organisation for Economic Co-Operation and Development.

Oltmer, J. (2010). Migration im 19. und 20. Jahrhundert. Enzyklopädie deutscher Geschichte, Band 86. München: Oldenbourg Wissenschaftsverlag.

Plane, D. A. (1993). Demographic influences on migration. Regional Studies, 27, 375-383.

Röder, W. (1992). Die Emigration aus dem nationalsozialistischen Deutschland. In K. J. Bade (Ed.), Deutsche im Ausland_Fremde in Deutschland. Migration in Geschichte und Gegenwart (pp. 345-353). München: C.H. Beck.

Rogers, A., \& Castro, L. J. (1981). Model migration schedules. Laxenburg: International Institute for Applied System Analysis, Austria.

Schlömer, C. (2009). Binnenwanderungen in Deutschland zwischen Konsolidierung und neuen Paradigmen. Bonn: Bundesinstitut für Bau-, Stadt- und Raumforschung.

Schönhuth, M. (2008). Remigration von Spätaussiedlern: ethnowissenschaftliche Annäherungen an ein neues Forschungsfeld. IMIS Beiträge, 33(2008), 61-83.

Steinert, J.-D. (1992). Drehscheibe Westdeutschland: Wanderungspolitik im Nachkriegsjahrzehnt. In K. J. Bade (Ed.), Deutsche im Ausland-Fremde in Deutschland. Migration in Geschichte und Gegenwart (pp. 386-392). München: C.H. Beck.

Venhorst, V. A., van Dijk, J., \& van Wissen, L. (2011). An analysis of trends in spatial mobility of Dutch graduates. Spatial Economic Analysis, 6(1), 57-82.

Zwysen, W. (2019). Different patterns of labor market integration by migration motivation in Europe: The role of host country human capital. International Migration Review, 53(1), 59-89. 
Open Access This chapter is licensed under the terms of the Creative Commons Attribution 4.0 International License (http://creativecommons.org/licenses/by/4.0/), which permits use, sharing, adaptation, distribution and reproduction in any medium or format, as long as you give appropriate credit to the original author(s) and the source, provide a link to the Creative Commons license and indicate if changes were made.

The images or other third party material in this chapter are included in the chapter's Creative Commons license, unless indicated otherwise in a credit line to the material. If material is not included in the chapter's Creative Commons license and your intended use is not permitted by statutory regulation or exceeds the permitted use, you will need to obtain permission directly from the copyright holder. 